\title{
Chlorpyrifos removal by Thiobacillus sp. and Clostridium sp. in liquid medium
}

\author{
Thalia Sunaryo $^{1}$, Hilarion Widyatmoko ${ }^{1}$, and Astri Rinanti ${ }^{1 *}$ \\ ${ }^{1}$ Universitas Trisakti, Environmental Engineering Dapartement, Faculty of Landscape Architecture and Environmental Technology, \\ Jakarta, Indonesia
}

\begin{abstract}
The bioremediation research of chlorpyrifos has been done to remove the concentration of chlorphyrifos using the natural bacterial Thiobacillus sp. and Clostridium sp.. The efficiency of chlorpyrifos removal was determined by the temperature and contact time. The research was done by adding $100 \mathrm{ppm}$ of chlorpyrifos into the Stone Mineral Salt solution (SMSs) under controlled condition, then each bacterial are added as much as $10 \%(\mathrm{v} / \mathrm{v})$ with $\mathrm{pH} 7$. To obtain optimum efficiency, this study was conducted with temperature variation $\left({ }^{\circ} \mathrm{C}\right) 25,30,35,40$ and contact time (hours) 12, 24, 36, 48. Based on Gas Chromatography Mass Spektrofotometer (GC-MS) analysis, the efficiency of removal at temperature $\left({ }^{\circ} \mathrm{C}\right)$ $25,30,35,40$ are $43 \%, 68 \%, 71 \%$ and $52 \%$ respectively, while the removal efficiency at contact time (hours) $12,24,36,48$ are $43 \%, 49 \%, 74 \%$, and $36 \%$. The result showed that $74 \%$ removal efficiency by Thiobacillus sp. and Clostridium sp. obtained at $35^{\circ} \mathrm{C}$ in 36 hours of contact time. Thus, the mixed culture of Thiobacillus sp. and Clostridium sp. are able to synergize for removing the chlorpyrifos at $100 \mathrm{ppm}$.
\end{abstract}

\section{Introduction}

Soil contamination is a condition where the source of artificial pollutants enter into the soil and can change the soil structure so that the soil ecosystem can not function properly. Some waste that can contaminate the soil is leachate waste containing chemicals and insecticides not only contaminate the soil but also the ground water and harm for the aquatic ecosystem. The accumulation of insectisides residue causes the pollution to the soil even the groundwater and surface water [1]

Surface water that contaminate by pesticides has negative effects on aquatic milieu, for example growth of fish [2]. The track of pesticides to entry the aqatic ecosystem begin from precipitaion, surface flow, atmospheric deposition to the aquatic ecosystem but also the non target organism that assosiated with agriculture [3-5]. Pesticide residues are also harmful to human health due to the absorption and accumulation into the food chain [6].

Chlorpyrifos is an effective non-systemic insecticide to kill various insects of plant and fruit pests [7]. Chlorpyrifos attack the insect nervous system by inhibiting the activity of acetylcholinesterase if ingested and inhaled into the respiratory system [8]. Chlorpyrifos is not only use in agriculture, but also to kill insects such as cockroaches and flies.

The hazard of chlorpyrifos residues can be manage through 3 processes, 1) Physical process using direct immobilization with activated charcoal either from rice husk or coconut shell [9], 2) Chemical process using active charcoal urea fertilizer with zeolite combined in
Fio (Inlet and Outlet Filters) placed on paddy fields, 3) Biological processes using bioremediation by microorganisms.

Bioremediation is the process of decomposing organic or inorganic pollutants using microorganisms such as fungi (Trametes hirsutus) and some types of bacteria in controlling contamination under controlled conditions into a harmless substance [10-11]. The advantage of bioremediation is to produce harmless products such as carbon dioxide, water and cell biomass also the hazardous compounds may change to harmless compounds [12]. The disadvantage of bioremediation is a requirment of controlled monitoring, and even the remediation process is slower than the chemical remediation.

Bioremediation can be applied by utilizing microorganisms such as fungi and bacteria. Several studies have proven that Pseudomonas aeruginosa can degrade residual chlorpyrifos [13]. The success rate of chlorpyrifos biodegradation depends on the concentration of chlorpyrifos in contaminated soil, the physiological microorganisms that will degrade chlorpyrifos, and the environmental conditions.

Based on these descriptions, this laboratory scale research is meant to study investigate potential of Thiobacillus sp. and Clostridium sp. as remediator of chlorpyrifos contamination in liquid medium [14].

\footnotetext{
* Corresponding author: astririnanti@trisakti.ac.id
} 


\section{Methods}

\subsection{Bacterial growth analysis}

Cultivation of Thiobacillus sp. and Clostridium sp. was done in batch culture using Stone Mineral Salt Solution (SMSs) medium, with composition $0.5 \mathrm{~g} \mathrm{CaCO}_{3} ; 2.5 \mathrm{~g}$ $\mathrm{NH}_{4} \mathrm{NO}_{3}$; one $\mathrm{g} \mathrm{Na}_{2} \mathrm{HPO}_{4} .7 \mathrm{H} 2 \mathrm{O}$; $0.5 \mathrm{~g} \mathrm{KH}_{2} \mathrm{PO}_{4} ; 0.5 \mathrm{~g}$ $\mathrm{MgSO}_{4} .7 \mathrm{H}_{2} \mathrm{O}$; and $0.2 \mathrm{~g}$ of $\mathrm{MnCl}_{2} .7 \mathrm{H}_{2} \mathrm{O}$ per liter. The composition contained in the erlenmeyer are $70 \%(\mathrm{v} / \mathrm{v})$ of the SMSs medium, Thiobacillus sp. and Clostridium sp. each of them $10 \%(\mathrm{v} / \mathrm{v})$ with a controlled $\mathrm{pH} 7$, and $10 \%(\mathrm{v} / \mathrm{v})$ with $10^{-2}$ dilution of molasses. Glucose, glycerol and molasses are added as carbon sources to increase microbial growth in this bioremediation [15].

Bacterial growth was calculated using the Total Plate Count method observed in Petri dishes that contained Nutrient Agar (NA) and calculated by Colony Counter by the formula:

$$
\begin{aligned}
& \text { Numbers of Colonies } / \mathrm{ml} \text { or / gram } \\
& =\text { Numbers of Colonies per petri dishes } x \frac{1}{\text { dillution factor }}
\end{aligned}
$$

\subsection{Chlorpyrifos removal test in liquid medium}

Chlorpyrifos removal test in liquid medium was done in two stages, as in the research design in Fig 1. The test was done by adding $10 \%(\mathrm{v} / \mathrm{v})$ chlorpyrifos in the erlenmeyer containing the bacteria Thiobacillus sp. and Clostridium sp. The environmental conditions are controlled by $\mathrm{pH} 7,100 \mathrm{ppm}$ of chlorpyrifos. Temperature and contact time were varied with the aim of finding the optimum conditions for Thiobacillus sp. and Clostridium sp. to remove the highest concentration of Chlorpyrifos. In the first stage of chlorpyrifos removal was tested with 4 variation of temperature i.e. $25,30,35$ and $40\left({ }^{\circ} \mathrm{C}\right)$ with $\mathrm{pH} 7$. Chlorpyrifos concentration was $100 \mathrm{ppm}$ and contact time was 48 hours. The results of the first stage to be the basic of the second stage with contact time variation $12,24,36$, and 48 by $\mathrm{pH}$. Chlorpyrifos concentration was $100 \mathrm{ppm}$ and the temperature used was the optimum temperature from the first stage.

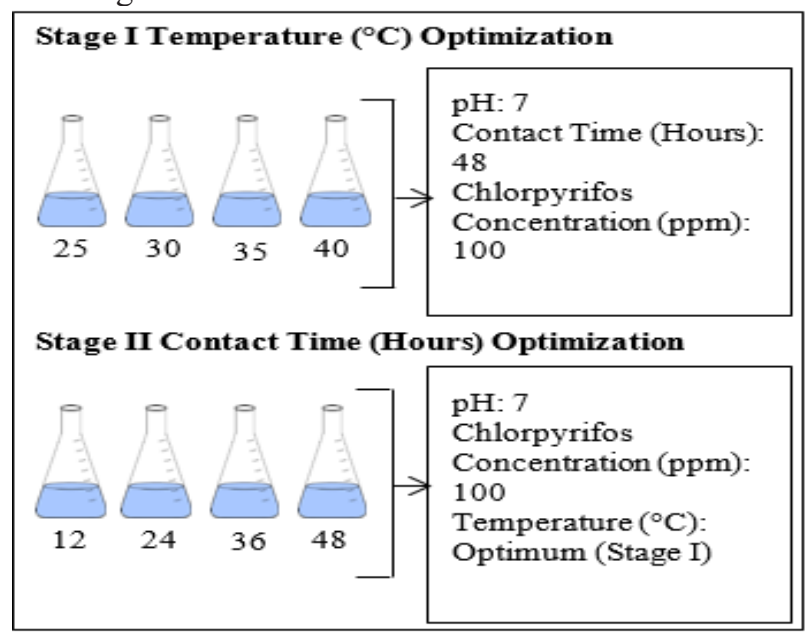

Fig. 1. Research Design.

\subsection{Analysis of Chlorpyrifos Removal in Liquid Medium}

Chlorpyrifos removal in liquid medium was analyzed using Gas Chromatography - Mass Spectrometry (GC MS) method [16]. Chlorpyrifos concentrations can be calculated by the formula:

$$
R=\frac{\frac{A u}{A b} \times c b^{\frac{V b}{V}} \times V e}{W u}
$$

Information:

$\mathrm{R}$ : Concentration of residual pastiside (ppm)

$\mathrm{Au}$ : Sample chromatogram area

Ab: The standard chromatogram area

$\mathrm{Cb}$ : The standard concentration (ng / $\mu \mathrm{l})$

Vb: Standard volume injected $(\mu \mathrm{l})$

$\mathrm{Vu}$ : The volume of the injected sample $(\mu \mathrm{l})$

Ve: The final volume of sample extract $(\mu \mathrm{l})$

$\mathrm{Wu}$ : Weight of sample (g)

\section{Results and discussion}

\subsection{The ability test of Thiobacillus sp. and Clostridium sp. in Chlorpyrifos}

The diameter zone of inhibition aims to determine the sensitivity of a bacteria to an antibiotic compound or pathogen compound [17]. The ability of bacteria Thiobacillus sp. and Clostridium sp. to survive in chlorpyrifos has been tested by exposing Thiobacillus sp. and Clostridium sp. into a Petri dish that contained Nutrient Agar (NA) and chlorpyrifos on a paper disc as in Fig 2.

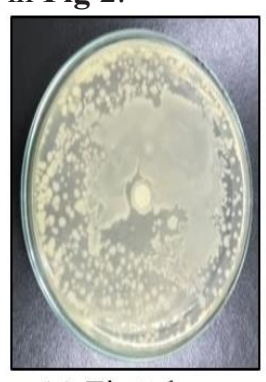

(a) First day

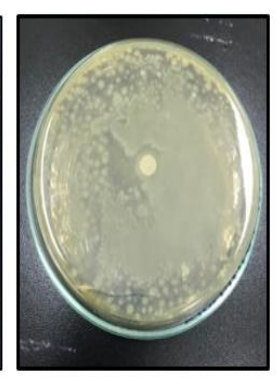

(b) Third day

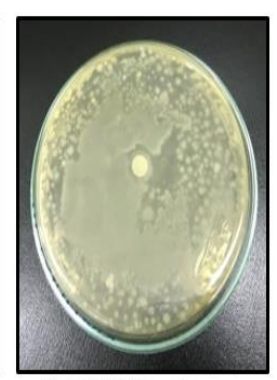

(c) Fifth day
Fig. 2. The ability of Thiobacillus sp. and Clostridium sp. In Chlorpyrifos

Based on Figure 2, there is no inhibition zone that is formed until the observation of the fifth day. This proved that Thiobacillus sp. and Clostridium sp. are abled to live and grow in an environment that contained chlorpyrifos.

\subsection{Chlorpyrifos removal in stage I}

In stage I, the sample was analyzed by tri replicated with the results as shown in Fig. 3. 


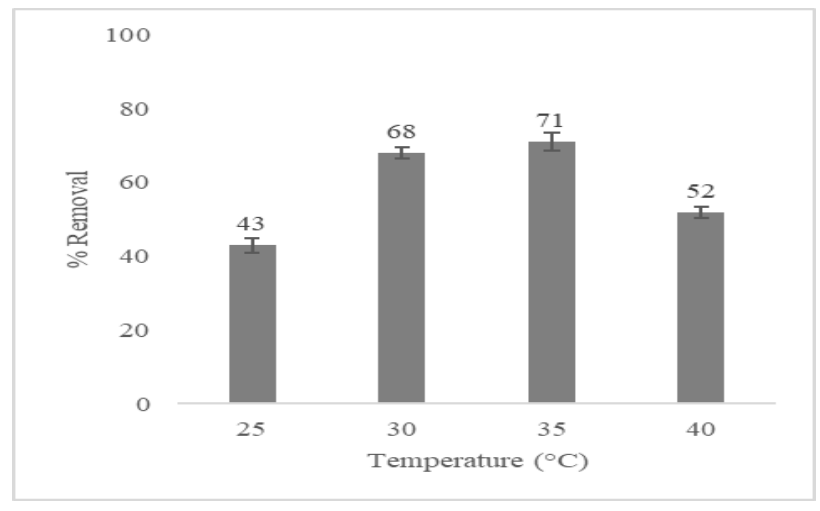

Fig. 3. \% Removal at temperature optimization.

Fig 3 shows that the highest chlorpyrifos removal occured at $35{ }^{\circ} \mathrm{C}$ is $71 \%$ and the lower removal occured at $25^{\circ} \mathrm{C}$ is $43 \%$. The removal of chlorpyrifos continues to increase along with the addition of temperature from 25 ${ }^{\circ} \mathrm{C}$ to $35{ }^{\circ} \mathrm{C}$. But at $40^{\circ} \mathrm{C}$ the chlorpyrifos removal decreased to $52 \%$. The result of the temperature optimization from $25,30,35,40\left({ }^{\circ} \mathrm{C}\right)$ occured at $35^{\circ} \mathrm{C}$. This happened because that temperature is suitable for the highest growth of Thiobacillus sp. and Clostridium sp. to remove the highest chlorpyrifos. This proved that Thiobacillus sp. and Clostridium sp. were able to remove chlorpyrifos at the optimum temperature, which is $35^{\circ} \mathrm{C}$.

Research [14] shows that chlorpyrifos with a concentration of $1000 \mathrm{mg}^{-1}$ can be degraded up to $89 \%$ with an optimum temperature of $35{ }^{\circ} \mathrm{C}$ by Bacillus pumilus C2A1. The highest percentage of chlorpyrifos removal by Thiobacillus sp. and Clostridium sp. occured at $35{ }^{\circ} \mathrm{C}$ reaching $71 \%$. This removal is $70 \%$ higher than the removal at $40{ }^{\circ} \mathrm{C}$ which reached $52 \%$.

\subsection{Chlorpyrifos removal in stage II}

In stage II, the sample was analyzed by tri replicated with the results as shown in Fig. 4.

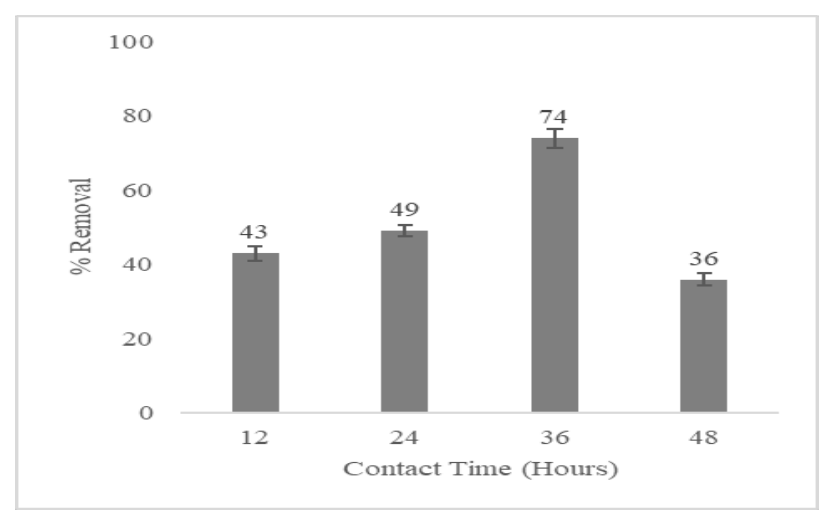

Fig. 4. \% Removal at Contact Time Optimization.

Fig 4 shows that the highest chlorpyrifos removal occured at 36 hours is $74 \%$ and the lower removal occured at 48 hours is $36 \%$. The removal of chlorpyrifos continues to increase along with the addition of contact time from 12 hours 36 hours. But at 48 hours the chlorpyrifos removal decreased to $36 \%$. The result of the contact time (hours) from 12, 24, 36, 48 occured at 36 hours. This happened because the optimum growth of Thiobacillus sp. and Clostridium sp. occured at 36 hours. Whereas, if the contact time is extend to 48 hours, the growth of Thiobacillus sp. and Clostridium sp. is decreasing along with the chlorpyrifos removal. This proves that Thiobacillus sp. and Clostridium sp. were able to remove chlorpyrifos at the optimum contact time, which is 36 hours. The previous study [18] showed that the removal of $150 \mathrm{mg} 1-1$ of chlorpyrifos by Bacillus cereus was $80 \%$ occurring at contact time for 5 days.

\section{Conclusions}

The results of this study, show that Thiobacillus sp. and Clostridium sp. were able to grow well in liquid medium that contained $100 \mathrm{ppm}$ of chlorpyrifos. In addition, Thiobacillus sp. and Clostridium sp. were able to remove chlorpyrifos up to $71 \%$ at $35^{\circ} \mathrm{C}$. Furthermore, the removal may reach $74 \%$ if contact time is shortened from 48 hours to 36 hours and set on $\mathrm{pH} 7$.

\section{References}

1. Banaee, M., Mirvagefei, A. R., Rafei, G. R., Majazi Amiri, B. Effect of sub-lethal Diazinon Concentrations on Blood Plasma Biochemistry. Int. J. Environ. Res. 2(2): 189-198, (2008)

2. Talebi, K. Diazinon Residues in the Basis of Anzali Lagoon, Iran. Bulletin Environmental Contamination Toxicol. 61: 477-483, (1998)

3. Vryzas, Z., Vassiliou, G., Alexoudis, C., Papadopoulou- Mourkidou, E. Spatial and temporal distribution of pesticide residues in surface waters in northeasterm Greece. Water Res., 43: 1-10, (2009)

4. Werimo, K., Bergweff, A.A., Seinen, W. Residue levels of organochlorines and organophosphates in water, fish and sediments from Lake VictoriaKenyan portion. Aquatic Ecosystem Health \& Management. 12: 337-34, (2009)

5. Arjmandi, R., Tavakol, M., Shayeghi, M. Determination of organophosphate insecticide residues in the rice paddies. Int. J. Environ. Sci. Technol. 7(1): 175- 182, (2010)

6. Mohammed, M.S. Degradation of methomyl by the novel bacterial strain Stenotrophomonas maltophilia MI. Electronic J. Biotechnol. 12(4): 1 6, (2009)

7. Thengodkar RRM, Sivakami S, Degradation of chlorpyrifos by an alkaline phosphatase from the cyanobacterium Spirulina platensis. 21: 637-644, ((2010)

8. Hui, T.J., Ariffin, M.M., Tahir, N.M., Hydrolysis of chlorpyrifos in aqueous solutions at different temperatures and pH. Malays. J. Anal. Sci. 14: 50$55,(2010)$

9. Asep Nugraha. Teknologi Arang Aktif untuk Pengendali Residu Pestisida di Lingkungan Pertanian. Balai Penelitian Lingkungan Pertanian. (2008)

10. Munir, E. Pemanfaatan Mikroba dalam Bioremediasi: Suatu Teknologi Alternatif untuk Pelestarian Lingkungan. Medan: USU, (2006) 
11. Vidali, M. Bioremediation. An overview. Pure Appl. Chem. 73: 1163-1172, (2011)

12. Kumar, A., Bisht, B.S., Joshi, V.D., Dhewa, T. Review on bioremediation of pollute d environment : A management tool. Int. J. Environ. Sci. 1(6): 0976 4402, (2011)

13. Lakshmi, C.V., Kumar, M., Khanna, S. Biotransformation of chlorpyrifos and bioremediation of contaminated soil. Int. Biodeter. Biodegr. 62: 204-209, (2008)

14. Anwar, S., Liaquat, F., Khan, Q.M., Khalid, Z.M., Iqbal, S. Biodegradation of chlorpyrifos and its hydrolysis product 3,5,6-trichloro-2-pyridinol by Bacillus pumilus strain C2A1. J. Hazard. Mater. 168: 400-405, (2009)

15. Samadi, N., Abadian, N., Akhavan, A., Fazeli, M.R. Biosurfactant production by the strain isolated from contaminated soil. J. Biol. Sci. 7: 1266-1269, (2007)

16. Alen.Y, Zulhudayati, Suharti.N. Pemeriksaan Residu Pestisida Profenofos pada Selada (Lactuca Sativa L.) dengan Metode Kromatogradi Gas. Jurnal Sains Farmasi \& Klinis. 1(2) : 140 - 149 (2015)

17. CLSI. Performance standards for antimicrobial disk and dilution susceptibility tests for bacteria isolated from animals; Approved standard. 3rd ed. CLSI document M31-A3. Clinical and Laboratory Standards Institute, Wayne, PA, (2008)

18. Liu, Z., Chen, X., Shi, Y., Su, Z. Bacterial degradation of chlorpyrifos by Bacillus cereus. $A d v$. Mater. Res. 356-360, 676-680, (2012) 